\title{
The Ethics of Government Whistleblowing
}

\author{
Candice Delmas
}

\begin{abstract}
What is wrong with government whistleblowing and when can it be justified? In my view, "government whistleblowing," that is, the unauthorized acquisition and disclosure of classified information about the state or government, is a form of "political vigilantism," which involves transgressing the boundaries around state secrets, for the purpose of challenging the allocation or use of power. It may nonetheless be justified when it is suitably constrained and exposes some information that the public ought to know and deliberate about. Government whistleblowing should then be viewed, along the lines of civil disobedience, as a collective cognition- and legitimacy-enhancing device.
\end{abstract}

Keywords: whistleblowing; leaks; vigilantism; national security; Edward Snowden; democracy; disloyalty

If the twentieth century was the age of civil disobedience, the twenty-first century is shaping up to be the age of whistleblowing. Whistleblowers have dominated the news and social media in the past year. Bradley (now Chelsea) Manning, who leaked over 750,000 classified documents to WikiLeaks, was recently sentenced to 35 years in prison. The Department of Justice is seeking to prosecute WikiLeaks' Julian Assange under the 1917 Espionage Act for publishing the secret documents leaked by Manning. Edward Snowden found temporary asylum in Russia after he blew the whistle on the National Security Agency's massive domestic and international surveillance program. For some people, Manning and Snowden acted heroically. For state representatives and White House officials, Manning's and Snowden's actions were "un-American" and "treasonous."

The public opinion appears ambivalent, both skeptical that Manning and Snowden are traitors and reluctant to call them heroes. ${ }^{1}$ Many news

${ }^{1}$ On the public opinion's divided view of Edward Snowden, see the following Reason-Rupe poll from September 2013: http://reason.com/poll/2013/09/19/poll-findspublic-split-on-whether-edwa2; and a YouGov/Huffington Post survey conducted in March 2014: https://today.yougov.com/news/2014/03/28/poll-results-snowden/. On the public view of Manning, see, e.g., this June 2013 Rasmussen Reports national survey: http://www.rasmussenreports.com/public_content/politics/general_politics/june_2013/52 _view_wikileaks_suspect_bradley_manning_as_a traitor. These polls suggest that public ambivalence is more pronounced with respect to Snowden than it is toward Manning. 
articles' headlines reflect this hesitation: "Traitor or Hero?" Ambivalence seems warranted: on the one hand, there are good reasons for condemning those who seize unlawfully and seek to disseminate national security information; on the other hand, leaks often play an important role in exposing serious government wrongdoing and informing the public debate, as the Pentagon Papers did in their times. This paper sketches an ethics of government whistleblowing that sheds light on both its prima facie wrongfulness and the conditions under which it may be justified (i.e., shown to be permissible).

"Government whistleblowing," as I shall understand it, involves the unauthorized acquisition (typically through mishandling or theft of protected documents) and disclosure (typically through leaks to a news outlet) of classified information about the state or government. To the extent that government whistleblowing, in my definition, involves the unauthorized disclosure of classified information about the state or government, it is illegal. Government whistleblowing is also by definition external, that is, outside approved organizational channels, whereas internal whistleblowing is conducted within the organization. The whistleblower may be an insider, that is, someone with current or former privileged access to the organization's data or information, or an outsider without privileged access. Manning, as an intelligence army analyst in Iraq, and Snowden, as a former CIA employee and NSA contractor, were insiders to the organization they denounced. Outsiders include, but are not limited to, journalists (such as The Nation's Jeremy Scahill, who blew the whistle on the rise of military contracting firms in the U.S. ${ }^{2}$ ), public intellectuals (think of Emile Zola's "J'Accuse!"), and activists (e.g., Russian anti-corruption activist Alexei Navalny).

The definition I just proposed does not attempt to precisely track our usage of the phrase "government whistleblowing," which we usually also apply to lawful revelations, such as Detective Frank Serpico's whistleblowing on the New York Police Department's widespread corruption. Serpico ultimately earned the praise of the City of New York and the federal government. For my purposes, what matters is that government whistleblowing is external and illegal, whereas "public whistleblowing," as I shall call lawful revelations about the state or government (or city), is typically internal and legally protected (at least when whistleblowers get things right). ${ }^{3}$ Government whistleblowing is also distinct from corporate whistleblowing, which involves disclosing information about a

\footnotetext{
${ }^{2}$ See Jeremy Scahill, Blackwater: The Rise of the World's Most Powerful Mercenary Army (New York: Perseus Books, 2007).

${ }^{3}$ The reality is much more complex than the distinction drawn here suggests. I return to this below.
} 
corporation's alleged misconduct, as Erin Brokovich did when she exposed Pacific Gas and Electric Company's toxic dumping in California. While ethicists have extensively discussed corporate and public whistleblowing, they have paid little attention to government whistleblowing in my sense. ${ }^{4}$ Yet blowing the whistle about government wrongdoing, to the extent that it involves stealing and leaking classified information about the state or government to outside sources, requires (at least presumptively) special justification.

Authorities' prohibition of government whistleblowing has particular weight in democratic societies, where obeying the law is a matter of respecting democratically enacted decisions. In nondemocratic or otherwise illegitimate states, on the other hand, government whistleblowing does not seem to be in special need of justification, though it clearly raises serious prudential dilemmas. The fact that criticizing the Soviet regime was illegal, for instance, did not make it presumptively wrong. As he alerted the world to the Gulag, Aleksandr Solzhenitsyn's dissent did not require special justification simply in virtue of being illegal. So my goal here is to justify government whistleblowing in less-than-perfect but basically democratic societies like those in North America and Western Europe. Though the argument I will develop in this paper is tailored for the United States context, and purports to evaluate the actions of government whistleblowers like Manning and Snowden, it sketches an ethics that can be applied to other basically liberal and democratic states.

The discussion proceeds as follows. First, I define whistleblowing in general (section 1.a) and distinguish government whistleblowing from other kinds of whistleblowing (1.b). Second, I examine four candidate accounts of the wrongfulness of government whistleblowing: namely, that it involves an impermissible breach of professional and promissory obligations (2.a), that it is unpatriotic (2.b), harmful (2.c), and amounts to vigilantism (2.d). The first, second, and third rationales fail to explain the wrongfulness of government whistleblowing, let alone support the claim that government whistleblowing can never be morally justified. I offer my own account of the wrongfulness of government whistleblowing in the fourth section on vigilantism: neither ordinary vigilantism (2.d.i) nor the kind of vigilantism at play in treason and espionage (2.d.ii), I argue, captures what is prima facie wrong with government whistleblowing, but a third kind of vigilantism does: "political vigilantism," as I call it, consists in transgressing the boundaries around state secrets, for the purpose of challenging the allocation or use of power (2.d.iii).

I turn to the justification of government whistleblowing, thus con-

${ }^{4}$ One exception is Sissela Bok, Secrets: On the Ethics of Concealment and Revelation (New York: Random House, 1983). 
ceived as a form of political vigilantism, in section 3. I argue that government whistleblowing may be justified even in democratic states when it meets three conditions: one, the state conceals from the public serious government wrongdoing or programs and policies that ought to be known and deliberated about (3.a); two, lawful attempts to make the information public are attempted first, unless they would be useless (3.b); and three, the whistleblower takes serious precautions so as to minimize the harms that could potentially ensue from the disclosure (3.c). In section 4, I suggest we think of government whistleblowing along the lines of civil disobedience, as a collective cognition- and legitimacy-enhancing device; and I consider a series of objections to my account centered on the notion that government whistleblowing is not civil.

\section{1.}

\section{1.a. Whistleblowing}

Whistleblowing in general consists in the intentional disclosure of information about an agent or entity's suspected illegal or unethical conduct. In his seminal analysis of whistleblowing, Peter Jubb identifies six main elements in whistleblowing:

(1) an act of disclosure (intentional release of information),

(2) an actor (a person with current or former privileged access to an organization's data or information),

(3) a disclosure subject (information about some wrongdoing that is deliberately kept from some people),

(4) a target (an organization),

(5) a disclosure recipient (an external entity having potential to remedy the wrong), and

(6) an outcome, namely, the disclosure's entry into the public domain. ${ }^{5}$

In Jubb's view, the specific difference between whistleblowing and other kinds of denunciation, such as informing and providing tips, lies in the stand that whistleblowers take when they make the information public: their disclosure amounts to an indictment of the wrongdoing. ${ }^{6}$ From this perspective, the whistleblower has more in common with the dissident, who opposes a perceived injustice, than with the informer, who trades an accusation for some personal benefit, such as a shorter sen-

${ }^{5}$ Peter B. Jubb, "Whistleblowing: A Restrictive Definition and Interpretation," Journal of Business Ethics 21 (1999): 77-94, pp. 83-88.

${ }^{6}$ Ibid., p. 79. 
tence. In this vein, Sissela Bok conceives of whistleblowing as a form of dissent (rather than denunciation) that includes an accusation. ${ }^{7}$

I shall not assume that the specific difference between whistleblowing and other kinds of denunciation is the indictment or accusation found in the former, because it appears that accusation can be salient at least in some cases of informing (Jorge Luis Borges's "Unworthy," for instance, tells the story of a man driven by his civic-mindedness to inform the police on a burglary that he is about to commit with other gangsters ${ }^{8}$ ). I agree, in any case, that dissent is a critical attribute of whistleblowing.

\section{1.b. Government whistleblowing}

Here are three examples of whistleblowers. First, a corporate whistleblower: Bradley C. Birkenfeld, who was a wealth manager at Crédit Suisse, disclosed information about the bank's fraudulent financial activities, including money laundering, accounting fraud, and violations of the Foreign Corrupt Practices Act, thereby leading to a successful enforcement action by the U.S. Internal Revenue Service. Second, a public whistleblower: Sergeant Joseph Darby, former U.S. Army Reservist, provided information to the U.S. Army Criminal Investigation Command about the Abu Ghraib detainee abuse scandal. Third, a government whistleblower: Daniel Ellsberg leaked the Pentagon Papers to The New York Times, thereby alerting the public to the U.S. war crimes in Vietnam and lying and deception at home. What differentiates corporate, public, and government whistleblowing?

To use Jubb's categories, I believe neither the actor, nor the subject, nor the target, nor the outcome of the disclosure helps differentiate between different kinds of whistleblowing. The whistleblower in each case is someone with privileged access to critical information; the subject is some suspected misconduct, that is, illegal or unethical activity; both public and government whistleblowing target the government or a state agency; and the intended outcome of all three kinds of whistleblowing, broadly conceived, is the entry of the information into the public domain. The main difference seems to lie in the act and recipient of whistleblowing. First, whereas corporate and public whistleblowers often act within the law by going through the proper channels of appeals, government whistleblowers, in my understanding, end up committing crimes by steal-

\footnotetext{
${ }^{7}$ Bok, Secrets, p. 214.

${ }^{8}$ Jorge Luis Borges, "Unworthy" ("El indigno"), originally published in Brodie's Report, August 1970. For more on the morality of informing, see Candice Delmas, "The Civic Duty to Report Crime and Corruption," The Ethics Forum/Les Ateliers de l'éthique 9 (2014): 50-64.
} 
ing and leaking classified information, even when they started by following protocol. Second, instead of reporting the information to the authorities, as corporate and public whistleblowers usually do, government whistleblowers transmit the information to the public (directly or indirectly via a news outlet).

In theory at least, public and corporate whistleblowing are viewed as crucial instruments of law enforcement in the private and public sectors. Thus as he took office in 2009, President Barack Obama praised whistleblowers, whom he described as "often the best source of information about waste, fraud, and abuse in government." In the U.S., a robust apparatus of federal and state law shields whistleblowers from employers' retaliation. The Lloyd-La Follette Act of 1912, for instance, guarantees the right of federal employees to furnish information to the U.S. Congress and protects them from wrongful dismissal. The Military Whistleblower Protection Act secures the right of members of the armed services to communicate with any member of Congress. The False Claims Act and the Dodd-Frank Wall Street Reform and Consumer Protection Act provide not only protections but also financial incentives to corporate whistleblowers by rewarding them with a share of the money they help the government save. Birkenfeld, for instance, was awarded \$104 million for blowing the whistle on Crédit Suisse.

However, such laws remain very limited in their scope (i.e., who is covered and how much is protected). Thus the 1989 Federal Whistleblower Protection Act, which shields government employees who reveal fraud and other wrongdoing from penalties and employer retaliation, does not protect NSA, FBI, and CIA workers or contractors. Neither does the 2012 Federal Whistleblower Protection Enhancement Act (WPEA), which expands the definition of "protected disclosure" and permits whistleblowers to collect compensatory damages, but excludes intelligence employees. Similarly, the most recent National Defense Authorization Act (NDAA), which offers military contract employees some whistleblower protections, excludes intelligence workers-both federal employees and contractors - from coverage under the act. While federal employees working in intelligence have scant whistleblower protections, compared with other federal workers, employees of federal contractors have no protections for whistleblowing under any of the laws and recent reforms. ${ }^{10}$

Add to this patchwork of limited protections the state's relative dis-

\footnotetext{
${ }^{9}$ See http://change.gov/agenda/ethics_agenda/.

${ }^{10}$ See, e.g., Mike Elk, "Snowden Leak Highlights Few Whistleblower Protections for Intelligence Contract Employees," In These Times, 11 June 2013, http://inthesetimes. com/working/entry/15130/snowden_leak_highlights_fewer_whistleblower_protections _ for_federal_contrac.
} 
cretion in enforcing these protections, so that it is difficult, in practice, to predict exactly when the law will be used to protect a given whistleblower, or instead to penalize her. All in all, the apparent distinction between public (internal and lawful) whistleblowing and government (external and unlawful) whistleblowing does not map well onto the phenomena. Public and corporate whistleblowers, frustrated by unresponsive headquarters or authorities, may decide to expose the misconduct to the public; and they will not necessarily be prosecuted for it. For instance, Peter Buxtun, employee of the United States Public Health Service, leaked information on the Tuskegee syphilis experiment to the Washington Star, after filing two official protests with the Service's Division of Venereal Diseases. He was not sued for going public. Conversely, public whistleblowers who only go through the proper channels and are supposed to be legally protected, may be retaliated against and even treated as criminals by the state. Four NSA whistleblowers before Snowden, who had pursued internal, lawful means of alert only, were harassed by the Federal Bureau of Investigation (FBI), and one of them, Thomas Drake, was prosecuted by the Department of Justice. ${ }^{11}$

Why are some whistleblowers praised and protected, but not others? The problem with government whistleblowing lies in part in the sensitive nature of the information that is disclosed to the public. By leaking classified information and bypassing the authorities, government whistleblowers seem to disregard the law and defy the state's authority. If whistleblowing is a form of dissent, as Bok argues, then government whistleblowing in particular may be deemed "subversive" or "transgressive" dissent. Far from being instruments of law enforcement, government whistleblowers are often treated as enemies of the state.

In this section, I examine four possible accounts of the wrongfulness of government whistleblowing, all of which might be taken to ground a categorical prohibition: first, government whistleblowing involves a breach of moral and professional duty (2.a); second, it betrays disloyalty to the state (2.b); third, it is harmful to particular individuals, national security, and public trust (2.c); and fourth, it amounts to vigilantism (2.d). As I shall show, each rationale fails to support the claim that government whistleblowing can never be morally justified; and all but the last one fail to explain what is prima facie wrong with it. The harm-based argument, however, successfully highlights the necessity of minimizing the

\footnotetext{
${ }^{11}$ I discuss the "NSA Four," as they came to be known, in more detail in section 3.b.
} 
harms that could potentially ensue from the disclosure-which is the second condition for justifiable government whistleblowing laid out below in 3.b. The fourth rationale is the most compelling; but neither ordinary vigilantism (2.d.i) nor the kind of vigilantism at play in treason and espionage (2.d.ii) capture what is prima facie wrong with government whistleblowing. I contend that government whistleblowing consists of a different kind of vigilantism - "political vigilantism"- that involves violating the moral duty to respect the boundaries around state secrets, for the purpose of challenging the allocation or use of power (2.d.iii).

\section{2.a. Breach of moral obligations}

Before working in certain government and state offices, employees and contractors have to pass security clearance. They often take an oath not to disclose classified information, which grounds a pro tanto moral duty to keep secret information secret, since, one might argue, we are morally bound by the promises we made freely. Snowden did not in fact swear an oath to secrecy - he swore an oath to protect and defend the Constitution. But one might still reasonably say that government employees and contractors like Snowden have a professional duty not to disclose classified information to third parties. ${ }^{12}$ Confidentiality is indeed expected of occupants of certain government offices, as part of their job. On most accounts of professional ethics, the demands of an office generally impose genuine moral demands on agents so long as the institution to which the office is attached has itself some value. ${ }^{13}$ Hence, cleared government employees typically have a moral (promissory and/or professional) obligation of confidentiality and are prohibited from disclosing classified information. This is the gist of the first argument against government whistleblowing.

Note the difference between insiders and outsiders: while Ellsberg, Manning, and Snowden were (supposed to be) morally bound not to disclose confidential information, The New York Times' Anthony Russo, who published the Pentagon Papers, Assange, and The Guardian's Glenn Greenwald, who published the Snowden leaks, were under no such duty. Indeed, the latter arguably discharged their professional responsibility as journalists by publishing the information; and they were protected by the freedom of the press. ${ }^{14}$ In contrast, the law did not protect, and profes-

\footnotetext{
${ }^{12}$ Note that I shall use "duty" and "obligation" interchangeably.

${ }^{13}$ See, e.g.: Emile Durkheim, Professional Ethics and Civic Morals (New York: Routledge, 1957); Mike W. Martin, Meaningful Work: Rethinking Professional Ethics (Oxford: Oxford University Press, 2000); Daniel Wueste, "Taking Role Moralities Seriously," The Southern Journal of Philosophy 29 (1991): 407-17; and Michael Hardimon, "Role Obligations," Journal of Philosophy 91 (1994): 333-63.

${ }^{14}$ There is debate over the question whether WikiLeaks should count as a news outlet,
} 
sional ethics did not appear not to justify, Ellsberg's, Manning's, and Snowden's leaks of classified information.

But are government employees morally bound not to disclose confidential information simply in virtue of having taken an oath, or occupying a certain office? I shall shortly examine the latter question concerning professional obligations, but I now want to address the question of the moral force of promises. Are we indeed morally bound by the promises we made freely, irrespective of the content of these promises? An affirmative answer would be implausible. Kimberley Brownlee has recently rebutted the voluntarist assumption that "promise-keeping has a general moral application that trumps other kinds of moral duty even when the conduct promised entails the performance of deeply objectionable acts." ${ }^{" 15}$ Christopher Moltisanti is not morally bound to kill rival capos just because he promised Tony Soprano he would do so. Neither is Christopher morally bound to keep silent if he promises not to tell anyone that Tony killed Salvatore "Big Pussy" Bonpensiero. Because the moral weight of promises depends at least in part on their content, promissory obligations don't trump other moral obligations.

Nevertheless, let us assume that the obligation of secrecy really provides government employees with a sufficient, ordinarily conclusive reason (a pro tanto duty) not to disclose confidential information. The question is whether the existence of this pro tanto duty entails that disclosure of classified information can never be justified. The answer is "no." David Cole recently observed that "[e]ven the most ardent security proponent must concede that the benefits from revealing illegal abuses of authority will sometimes outweigh the costs of disclosing those secrets." ${ }^{\text {"T }}$ Though the duty to keep secrets weighs very heavily on the balance of reasons, other considerations, such as the duty to report government abuse, or the prospect of benefiting public deliberation, may sometimes outweigh it. Disclosure may then be justified.

A champion of secrecy will reply that the professional and moral duty not to disclose is such that it prevents the agent from engaging in any

and Assange as a journalist, and whether he is entitled to the strong legal protections associated with freedom of the press. See, e.g.: Jonathan Peters, "WikiLeaks Would Not Qualify to Claim Federal Reporter's Privilege in Any Form," Federal Communications Law Journal 63 (2011): 667-96; Geoffrey R. Stone, "WikiLeaks, the Proposed SHIELD Act, and the First Amendment," Journal of National Security Law and Policy 5 (2011): 105-18; Mary-Rose Papandrea, "The Publication of Classified Information in the Digital Age,” Journal of National Security Law and Policy 5 (2011): 119-30.

${ }^{15}$ Kimberley Brownlee, Conscience and Conviction: The Case for Civil Disobedience (Oxford: Oxford University Press, 2012), p. 112.

${ }^{16}$ David Cole, "The Three Leakers and What to Do About Them," The New York Review of Books, 6 February 2014. 
balancing of reasons at all. On this view, the duty supplies not only a first-order reason for action, but a second-order reason to disregard reasons against it. Joseph Raz calls duties of this sort "exclusionary."17 The paradigmatic exclusionary duty, for Raz, is the duty to obey the law. As he explains, the existence of a legal rule purports to preempt the individual's assessment of the merits of the action legally required. The duty of secrecy also appears exclusionary in nature.

Some philosophers hold that role-occupants' failure to conform to the formal duties attached to their role (e.g., as judge or soldier) threatens valuable institutions (the judiciary or the army) by undermining confidence in their functioning. ${ }^{18}$ Indeed, one might insist that the duties that flow from a given role are justified - and the exclusionary claim successful - just in case the institution served by the role is itself valuable. It is beyond the scope of this paper to fully critique this view, but I want to suggest that when professional duties conflict with other moral considerations, it is an open question how these conflicts should be resolved.

Contra the view just mentioned, Brownlee shows that "there is an ineliminable conceptual and evaluative gap between the formal codifiable dictates of normatively legitimate offices and positions and the broadly non-codifiable moral responsibilities of the moral roles that underpin and legitimate those positions" (she calls this the "gap thesis"). ${ }^{19}$ The existence of this gap is unavoidable given the "rigidifying and generalizing nature of formal institutions," that is, the fact that they necessarily issue formal dictates that ignore context-sensitive ways of satisfying the responsibilities at the heart of a certain role. Because the gap is unavoidable, it translates into frequent conflicts between the responsibilities that underlie one's role and the office's formal dictates. In cases of conflicts, Brownlee argues, "it is morally obligatory ceteris paribus to depart from formal expectations and to adhere to our moral responsibilities" (she calls this the "moral roles thesis"). ${ }^{20}$

Albeit very brief, this summary of Brownlee's arguments outlines a methodic defense of the view that office-holders' general moral responsibilities should take precedence over their professional dictates and promissory obligations when the two come into conflict. While I have not provided any reasons to endorse Brownlee's gap thesis and moral roles thesis, historical evidence regarding the dangers of unquestioning

\footnotetext{
${ }^{17}$ Joseph Raz, The Authority of Law (Oxford: Oxford University Press, 1979), pp. 3-36.

${ }^{18}$ See, e.g.: David Estlund, "On Following Orders in an Unjust Law," Journal of Political Philosophy 15 (2007): 213-34; Hardimon, "Role Obligations"; Joel Feinberg, Problems at the Roots of Law (Oxford: Oxford University Press, 2003).

${ }^{19}$ Brownlee, Conscience and Conviction, p. 86.

${ }^{20}$ Ibid., p. 87.
} 
adherence to formal roles suggests skepticism toward the opposing view. At the very least, one should allow for the possibility that breach of the duty not to disclose may sometimes be justified.

\section{2.b. Patriotic disloyalty}

Another potential problem with government whistleblowing is that it involves betrayal of one's country or state (I want to retain the ambiguity of the two terms, "country" and "state," for now). At least in the United States, government whistleblowers are often accused of, and sometimes also charged with, treason and espionage, which convey disloyalty. Treason presupposes a preexisting duty of allegiance or loyalty based on political membership (and hence only applies to citizens). ${ }^{21}$ This duty is both a moral duty and a legal duty, explicitly recognized, for instance, in the Naturalization Oath of Allegiance to the United States of America.

From this perspective, what is wrong with government whistleblowing, one might contend, is that it involves betrayal of, or intent to betray, the state - in short, patriotic disloyalty. Although I am not aware of any account of patriotic disloyalty, philosophers have offered myriad accounts of patriotic loyalty. Stephen Nathanson, for instance, characterizes patriotism by four qualities: "Special affection for one's country, a special identification with it, special concern for its well-being, and a willingness to sacrifice to promote the country's good." 22 Disloyalty, presumably, involves not only lack of such feelings and dispositions toward one's country, but also negative feelings and dispositions toward it.

Does government whistleblowing involve patriotic disloyalty, thus broadly conceived? A reasonable answer is that it depends on the whistleblower. President Obama denied that Snowden was a patriot. Nathanson observed, on the contrary, that "Mr. Snowden has certainly made a significant personal sacrifice, and there is so far no evidence that he was motivated by anything other than concern for his country." 23 Snowden indeed explicitly denied his intention to betray the U.S.: "I did not seek to enrich myself. I did not seek to sell U.S. secrets. I did not partner with any foreign government to guarantee my safety." 24 Instead, he affirmed

\footnotetext{
${ }^{21}$ See, e.g.: Alasdair MacIntyre, After Virtue, 2nd ed. (Notre Dame: University of Notre Dame Press, 1984); Yael Tamir, Liberal Nationalism (Princeton: Princeton University Press, 1993); and Bas van der Vossen, "Associative Political Obligations," Philosophy Compass 6 (2011): 477-87.

${ }^{22}$ Stephen Nathanson, Patriotism, Morality, and Peace (Lanham, Md.: Rowman \& Littlefield, 1993), p. 134.

${ }^{23}$ Stephen Nathanson, "Letter to the Editor," New York Times, 10 August 2013; http://www.nytimes.com/2013/08/13/opinion/obamas-defense-of-surveillance.html.

${ }^{24}$ Statement by Edward Snowden to human rights groups at Moscow's Sheremetyevo
} 
his intention to protect the Constitution of the United States. Snowden, Manning, and Ellsberg have been hailed by some as "true patriots." There is no reason to think that patriots must abide by the law and would never condemn their country. ${ }^{25}$

Part of what may ground the difference between Obama's and Nathanson's verdict is that Obama appears to equate patriotism with "allegiance to the state," that is, respect for and compliance with the system of institutions and laws, whereas Nathanson focuses on the agent's attitude toward her country, understood to comprise a certain historical, social, and political community. Nathanson's account fits better with our ordinary conception of patriotic (dis)loyalty as lying in the agent's intentions and motivations first. His account further allows for the possibility that agents might break the law out of patriotism, whereas Obama's understanding makes it impossible by definition.

Nathanson stresses that "[w] hether Mr. Snowden is a patriot and whether he acted rightly are two different questions," adding: "[m]any patriotic people have carried out or supported actions that have been harmful to their country." 26 We identify patriotism or disloyalty by searching the agent's motives; we evaluate the rightness or wrongness of the action by examining its consequences. And so, knowing that someone acted out of loyalty or out of disloyalty does not settle the question whether one's action was justified.

One may object that there is an asymmetry between patriotic and unpatriotic motives: although patriotic motives are neither necessary nor sufficient to justify an action, patriotic disloyalty is sufficient to show an action is impermissible. This is mistaken, however. For one, people may do the very same thing out of patriotic or unpatriotic intentions (such as voice dissent against the War in Afghanistan), and it would seem wrong to condemn one but not the other act on the basis of the agent's motives. Patriotic disloyalty may further be an appropriate response to a country's repressive history, as many Germans argued after World War II, so that a decision to emigrate or refuse to sing the national anthem, for example, would be perfectly permissible.

What should concern us is whether the agent's disloyalty led her to attempt to injure the state - in a context where the state is legitimate and ought to be preserved. So, the wrong-making feature of the action does not lie in the agent's unpatriotic motivations, but in its potentially harmful effects.

airport, 12 July 2013; http://wikileaks.org/Statement-by-Edward-Snowden-to.html.

${ }^{25}$ See, e.g., Simon Keller's discussion of "patriotic dissidents" in "Patriotism as Bad Faith," Ethics 115 (2005): 563-92, pp. 573-74.

${ }^{26}$ Nathanson, "Letter to the Editor." 


\section{2.c. Harm}

There are three ways of cashing out the harm-based argument against government whistleblowing: government whistleblowers (i) threaten the safety of particular individuals, (ii) endanger national security, and (iii) damage public trust.

2.c.i. Particular individuals' safety. Divulging the identity of agents in covert operations immediately puts their life under threat of death; and disclosing top-secret information about ongoing and upcoming military operations endangers troops' safety. I shall not dispute this point, but simply note that it does not warrant wholesale condemnation of government whistleblowing, since the information released can be - and ought to be-carefully edited, as I will argue in section 3 .

2.c.ii. National security. Under U.S. law, and in many other countries, the crime of treason carries a possible death sentence. The rationale for this is that although the traitor may not have killed anyone (the usual justification for the death penalty), his or her actions endanger the safety of particular people as well as the whole community, and are in some sense morally comparable to killing. U.S. espionage law reflects the damage done to the state, as it applies to "[w]hoever knowingly and willfully communicates, furnishes, transmits, or otherwise makes available to an unauthorized person, or publishes, or uses in any manner prejudicial to the safety or interest of the United States or for the benefit of any foreign government to the detriment of the United States any classified information. $" 27$ This may indeed be the most oft-heard - and seemingly compelling - reason for categorically condemning government whistleblowing: leaks of classified information endanger national security.

The government's national-security argument against whistleblowing goes something like this. Just as individuals need control over their private information in order to protect their autonomy (such as their relationships and plans in the making), so the government claims a fundamental interest in concealing, and having exclusive control over, certain information for the sake of effective governance. Protecting national security (including cybersecurity) is the main function for which governments claim they need secrecy. ${ }^{28}$

The state's interest in concealing certain information, such as details about secret military operations, is widely accepted. I shall accept it, too,

\footnotetext{
${ }^{27} 18$ USC $\S 798$ (my emphasis).

${ }^{28}$ They also evoke the need for secrecy in other realms, such as with respect to international negotiations. See Bok, Secrets, pp. 181-87.
} 
and not just for the sake of argument: I do not find WikiLeaks' or the hacktivist group Anonymous' crusade for absolute transparency (if I understand correctly what they are after) particularly compelling. But the difficulty is to determine the legitimate scope of state secrecy. The government asks the public to trust it when it comes to delineating that scope, on the grounds that an open debate about what should and should not be kept hidden from the public would itself endanger national security. Bok cites a U.S. official arguing that publishing "examples, reasons, and assorted details" regarding the government's strategy in the Cold War "would certainly damage the nation's interests.",29

Recent examples concerning the alleged, but in fact merely apparent, dangers of transparency in the context of the war on terror abound. Until Hamdan v. Rumsfeld, the Combatant Status Review Tribunals established by the Department of Defense for persons held in Guantánamo Bay did not permit defendants and their lawyers to see or rebut the evidence on the basis of which they were tried and convicted - allegedly for the sake of protecting national security. ${ }^{30}$ Yet compliance with minimal due process guarantees in the trials of Guantánamo detainees since 2006 has not endangered national security. For another example, the government refuses to divulge the criteria used to decide who gets on terrorist watch lists such as the Terrorist Screening Database and the no-fly list. Although the lists generate many false positives, since anyone who shares the name of someone on the list will be treated as a suspect, including children, it is nearly impossible to legally challenge the designation. Legal scholars have argued that these practices are unlawful, unduly restrictive, and unethical; and the state has not explained why legal challenges would threaten national security. ${ }^{31}$

As these examples illustrate and history demonstrates, the government makes claims concerning the necessity to operate behind closed doors to protect national security much more often than necessary, and in a way that often constitutes abuse of power. The point of the political system of checks and balances is to check these claims, and halt these abuses by the executive. But the system is fallible, to say the least.

It is an open question how much and to what extent state secrets are necessary for success in war and counterterrorism, and whether their disclosure automatically damages the nation's interests. Though the government affirmed that the release of the Pentagon Papers endangered the troops in Vietnam and threatened national safety, no empirical evidence

\footnotetext{
${ }^{29}$ Ibid., pp. 202-3.

${ }^{30}$ Hamdan v. Rumsfeld 548 US 557 (2006).

${ }^{31}$ See, e.g., Anya Bernstein, "The Hidden Costs of Terrorist Watch Lists," Buffalo Law Review 61 (2013): 461-535.
} 
came to validate these fears. U.S. officials' claims that China and Russia would seize the Snowden leaks have not been confirmed either. Manning's leaks of diplomatic cables certainly embarrassed the government, but they do not appear to have injured the United States. In light of the state's tendency to abuse its exclusive control over secrecy, the harmbased argument does not warrant categorically prohibiting leaks of classified information.

2.c.iii. Public trust. Here is another standard by which to judge the potential harms of government whistleblowing, besides the threat to personal safety and national security: decline of public trust. Henry Kissinger argued that the purpose of "those who stole" the Pentagon Papers was to "undermine confidence in their government" and "raise doubts about our reliability in the minds of other governments, friend and foe, and indeed about the stability of our political system.,"32 Officials argue that government whistleblowers weaken trust in government and public servants.

I think this is correct. The Watergate scandal, the Pentagon Papers, and the Snowden leaks, to take just a few examples, certainly damaged public trust in the government. The question is whether it is right to deplore decline of trust in institutions that fail to deserve trust. Insofar as trust is not good in and of itself, but ought to be cognitively grounded, that is, based on reasons, its decline should not be lamented. Trustworthiness is what matters. ${ }^{33}$ Trusting an incompetent, corrupt, or malevolent government to serve the public good is not desirable; indeed citizens may have a prima facie obligation to undermine untrustworthy governments. From this perspective, not only does leaks' potential damage to public trust not warrant categorical prohibition, but government whistleblowing can serve a valuable function - enhancing institutions' trustworthiness by pointing out their failures.

This is not to say that any and all shortcoming of public offices should always be exposed to the public, especially if the information's entry into the public domain can be expected to have toxic effects more serious than the wrongdoing that was exposed. Distrust has been observed to "spill over" from agent to agency and from one agency to another in the political context. ${ }^{34}$ One should keep this phenomenology of

\footnotetext{
${ }^{32}$ Henry Kissinger, The White House Years (Boston: Little Brown \& Co., 1979), p. 730; cited in Bok, Secrets, p. 207.

${ }^{33}$ See, e.g.: Onora O'Neill, A Question of Trust: The BBC Reith Lectures 2002 (Cambridge: Cambridge University Press, 2002); Mark E. Warren (ed.), Democracy and Trust (Cambridge: Cambridge University Press, 1999); Russell Hardin, Trust (Cambridge: Polity Press, 2006).

${ }^{34}$ See Gabriella R. Montinola, "Corruption, Distrust, and the Deterioration of the Rule of Law," in Russell Hardin (ed.), Distrust (New York: The Russell Sage Foundation,
} 
distrust in mind when seeking to expose institutional shortcomings. In his discussion of the moral force of law in Summa Theologica, Aquinas argues that subjects faced with unjust laws that are "contrary to the human good" (which do not bind in conscience) must cautiously and thoughtfully weigh the expected costs and benefits of disobedience against those brought about by compliance with the law. ${ }^{35}$ The conclusion of deliberation may be that one should obey the law, if disobedience would cause "scandal or disruption," in Aquinas's words; or that one ought to disobey, if leaving the law unchallenged would be worse.

The same may be said about exposing certain official and institutional wrongs: one should carefully compare the consequences of disclosure against those of inaction. Some official wrongs, such as war crimes, may be said to be so grave as to necessitate public exposure no matter what ensues. Others, such as public officials' extramarital affairs, do not deserve the same level of exposure (if any). Thus I shall stand by my position that trustworthiness is what matters, but also stress the importance of weighing the benefits of disclosure against its possible toxic effects when deliberating about whether to blow the whistle on some state secret. In short, the subject and manner of leaking matter a lot, as I shall further explain in sections 3.a and 3.c.

\section{2.d. Vigilantism}

2.d.i. Crime-fighting vigilantism. What is wrong with government whistleblowing, one might argue, is that it amounts to an impermissible form of vigilantism that undermines the rule of law. According to John Locke, people surrender the two powers they have in the state of nature upon entering the civil society, namely, the "natural right to do whatsoever [one] thinks fit for the preservation of [oneself] and others within the permission of the law of nature," and the "natural right to punish and be the executor of the law of nature." 36 Through the social contract, they transfer these two powers or rights to the sovereign, and thereby constitute political authority. On this picture, vigilantes do wrong because they retain one or both of these rights, and thus violate the social contract.

Neighborhood watches and superheroes usually come to mind when we think of vigilantism. Following Travis Dumsday, let us understand

\footnotetext{
2004), pp. 298-323.

${ }^{35}$ Unfair tax laws and laws that originate ultra vires belong to this category. Thomas Aquinas, Summa Theologica (New York: Cosimo, 2007), Q. 96, art. 4. For discussion of Aquinas's position, see Norman Kretzmann, "Lex Iniusta Non Est Lex: Laws on Trial in Aquinas' Court of Conscience," The American Journal of Jurisprudence 33 (1988): 99-122.

${ }^{36}$ John Locke, Second Treatise of Government, ed. C.B. Macpherson (Indianapolis: Hackett, 1980 [1690]), § 128.
} 
ordinary crime-fighting vigilantism as "the organized use of violence or threat of violence by an agent or agents who are not willingly accountable to the state, for the purpose of controlling (preventing and/or punishing) criminal or noncriminal but still deviant actions." ${ }^{37}$ Vigilantes use or threaten violence to fight crime; and they do so independently, and in contravention, of the state. They wrongfully hold on to the "natural right to punish and be the executor of the law of nature" and usurp lawenforcement functions, especially police powers. ${ }^{38}$ Something at least vaguely like this may be going on with government whistleblowing; but examination of another kind of vigilantism, recently conceptualized by Youngjae Lee, gets us closer to the mark.

2.d.ii. Foreign relations vigilantism. Lee proposes to understand treason and espionage as "foreign relations vigilantism." 39 What is wrong with these crimes, he submits, "is that they cross the boundaries that are set up to protect the state monopoly of violence." 40 The state claims a legitimate monopoly on the use of coercive force, as a necessary condition for order and self-protection. This monopoly on violence, according to Lee, is the central feature of the configuration or allocation of power between the state and its citizens. Because their compliance with this configuration is required for the state's ability to fulfill its mission, citizens have a moral duty to respect the state's allocation of power.

"When a citizen participates in efforts to undermine the core institutional resources the state requires to protect itself" (such as police, military forces, and intelligence agencies), Lee explains, "the citizen disturbs the way in which power is distributed within the polity and enters a domain of exclusive governmental power ... [T] he relevant wrong here should be thought of as usurpation of state power." ${ }^{41}$ Traitors and spies transgress this configuration by directly or indirectly attempting to undermine "core institutional resources the state requires to protect itself ... or to otherwise advance its interests by force." ${ }^{, 42}$ Foreign relations vigilantism, on Lee's view, is prima facie wrong insofar as it involves a breach of the moral duty to respect the allocation of state power.

\footnotetext{
${ }^{37}$ Travis Dumsday, "On Cheering Charles Bronson: The Ethics of Vigilantism," The Southern Journal of Philosophy 47 (2009): 49-67, p. 58.

${ }^{38}$ This isn't Dumsday's view of what is wrong with vigilantism. On his account, vigilantism is prima facie wrong insofar as it violates citizens' moral duty to obey the law. Dumsday, "On Cheering Charles Bronson," p. 59.

${ }^{39}$ Youngjae Lee, "Punishing Disloyalty? Treason, Espionage, and the Transgression of Political Boundaries," Law and Philosophy 31 (2012): 299-342, p. 304.

${ }^{40}$ Ibid., p. 335.

${ }^{41}$ Ibid., p. 336.

${ }^{42}$ Ibid., p. 306.
} 
The prosecution of government whistleblowers as traitors and spies seems to suggest that they might be engaged in exactly the kind of transgression of the boundaries of state power that Lee describes. However, further reflection on the nature and aims of government whistleblowing indicates that the transgression in question is of a very different kind. In particular, it is inaccurate and unhelpful to describe government whistleblowers' transgression as an arrogation of power (which characterizes both crime-fighting and foreign relations vigilantes) or as aiming to injure the state (the essence of foreign relations vigilantism).

2.d.iii. Political vigilantism. My suggestion is that the vigilantism at the heart of whistleblowing consists in transgression of the boundaries around state secrets, for the purpose of challenging the allocation or use of power. I propose to call this "political vigilantism." The crucial difference between traitors and whistleblowers is that while the former attempt to undermine core institutional resources, the latter purport to challenge the allocation or use of state power, that is, the ends for which, and manner in which, the state's institutional resources are deployed, including the state's determination of the proper scope of secrecy. In short, political vigilantes aim to expose to the public, and thus question the legitimacy of, the boundaries around state secrets that they cross.

This understanding of government whistleblowing as a form of vigilantism provides a persuasive rationale for its wrongfulness. It can further account for the concerns underlying the two previous accounts, which were centered on disloyalty (2.b) and harm (2.c): the loyalty flouted by government whistleblowers is that which demands respecting the state's configuration of power; and the harm of government whistleblowing consists in disturbing that configuration. The wrong of political vigilantism (and of other forms of vigilantism) thus lies in its breach of the moral duty to respect the allocation of power. Yet showing that government whistleblowing amounts to political vigilantism is not sufficient to ground its categorical condemnation. Both Dumsday and Lee argue that the particular brand of vigilantism they are interested in can sometimes be justified. In the next section, I shall show the same about political vigilantism.

\section{3.}

What must be true of the state before it generates a duty to respect its allocation of power? Although all states, good and bad, claim the need to unilaterally determine and control the allocation of power, there cannot be a moral duty to abide by tyrannical states' configuration of power. Indeed there is a moral right, perhaps even a duty, to interfere with a 
tyrannical allocation of power. Presumably, only subjects of legitimate (de jure, not simply de facto) states have a duty to respect the state's boundaries of power. If legitimacy is a matter of degree, as one may plausibly argue, democratic societies should have the strongest claim to generating a duty to respect the state's allocation of power, since this allocation has been determined collectively, in a way that reflects concern for all citizens. In turn, nondemocratic and authoritarian states would only have a weak claim, if any, to imposing on their subjects a duty to respect the boundaries of state power. In such states, political vigilantism may not be prima facie wrong (or, to put it differently, the duty to respect the allocation of power would be easily defeated).

Take Chinese dissident and artist Ai Weiwei, who has blown the whistle on his government's inertia in the wake of the 2008 Sichuan earthquake. The government having failed to record the casualties, Weiwei compiled and published on his blog the list of children killed. His tallying of the tragedy's deaths, and documentation of the government's failure to react in a timely and appropriate manner, disrupted the allocation of state power, insofar as counting the dead and taking care of the injured and sick in times of emergency are among the state's basic functions (think of the state's control of the plague-stricken city in Michel Foucault's Discipline and Punish). Weiwei's activism constitutes an interference with the state's allocation of power; and it was treated as such: he was brutally assaulted by the police shortly afterwards and recorded the incident and his convalescence. ${ }^{43}$ His activism clearly qualifies as political vigilantism, that is, transgression of the boundaries of power, carried out to contest the state's failure to react to the earthquake. Though very dangerous in the Chinese context, it does not appear presumptively wrong, given (or assuming) China's serious legitimacy deficits.

In contrast, there is a strong case against interfering with the configuration of power in democratic states, where people collectively determine the allocation of power. Political vigilantism would then wrongfully contravene the people's will or democratic sovereignty. Moreover, in democratic states governed by the rule of law, part of the configuration of power involves an institutionalized system of checks and balances designed to prevent executive abuse of power and oversee the ends for which, and manner in which, the state's institutional resources are deployed, including the government's determination of the proper scope of secrecy. And so, in crossing the boundaries of state power, government whistleblowers appear to usurp legitimate state powers and flout democratic authority.

Although the duty to respect the allocation of state power is the weight-

${ }^{43}$ See Ai Weiwei: Never Sorry, documentary film directed by Alison Klayman (2012). 
iest in deliberative democracies, it is not absolute, but may sometimes be outweighed. Government whistleblowing may then be justified. Hence the first condition for the justification of government whistleblowing:

(A) The subject condition: The moral duty to respect the allocation of state power is overridden - and government whistleblowing may be justified-when the state conceals from the public serious government wrongdoing or programs and policies that ought to be known and deliberated about.

The preceding discussion of the prima facie wrongfulness of whistleblowing further suggests the following two conditions for the justification of government whistleblowing:

(B) The act condition: The act (i.e., unlawful acquisition and disclosure of secret information) should generally be undertaken after lawful attempts to make the information public have been attempted, unless there are reasons to think these would be useless; and

(C) The minimize harms condition: The whistleblower should take serious precautions in the disclosure so as to minimize the harms that could potentially ensue, including carefully choosing the leaks' recipients and editing the information.

When government whistleblowing satisfies these three conditions, it may be a morally justified (i.e., at least permissible, if not also obligatory) interference with the state's allocation of power. ${ }^{44}$ My claim, however, is not that the subject condition, the act condition, and the minimize harms condition are necessary and sufficient for the justification of government whistleblowing. They should instead be viewed as ceteris paribus constraints on justifiable government whistleblowing.

\section{3.a. The subject condition}

First, the moral duty to respect the boundaries or allocation of state power, though ordinarily conclusive in democratic states, may sometimes be overridden. The duty may be weakened or defeated by significant "informational deficits," as I shall refer to them, that arise when the public is kept in ignorance of serious government wrongdoing (such as its commission of human rights abuses) or programs and policies that ought to be known and collectively debated (such as domestic surveillance). This first condi-

\footnotetext{
${ }^{44}$ I focus here on the permissibility of government whistleblowing. For a discussion of its obligatoriness, see Delmas, "The Civic Duty to Report Crime and Corruption."
} 
tion thus concerns the subject of whistleblowing, that is, that which is being disclosed. Basically, the subject is appropriate - and the moral duty to respect the allocation of state power is overridden-when secrecy threatens or stains political legitimacy. So, for unlawful leaks of classified information to be justified, they must be undertaken to remedy significant informational deficits and inform the public.

The Pentagon Papers justifiably exposed the U.S. commission of war crimes in Vietnam, which the government was concealing from the public. The first revelation to come out of Manning's leaks of the Afghanistan and Iraq War Logs was the graphic video of a U.S. Apache helicopter airstrike of unarmed civilians in Baghdad. "Collateral Murder," as the video became known as, contributed to changing the way the public viewed the war, instilling in particular a healthy dose of skepticism about the government's talk of "surgical strikes." Manning also leaked 250,000 State Department cables, which revealed prisoner abuse by the Iraqi military and routine failures on the part of the U.S. to investigate them. Arguably, Ellsberg's and Manning's disclosures contributed to informing the public debate about serious government misconduct, which stained U.S. legitimacy.

The programs and policies kept secret that the public ought to know and deliberate about need not involve straightforward wrongdoing or illegality. It may simply be the fact of the public's ignorance that is problematic and threatens political legitimacy. Another important revelation to come out of Manning's leaks was the count of the civilian and military casualties in the conflicts in Iraq and Afghanistan. The tally of deaths was not wrong in and of itself; but the fact that the White House had denied being in its possession was seriously objectionable.

In general, the government tends to keep secret those programs whose legality is hard to defend, the CIA's black sites and the NSA's domestic spying program being cases in point. Snowden insisted that the state's efforts to cover the surveillance program under the cloth of legality (via the FISA court) did not make the program constitutionally sound. A federal judge recently agreed with Snowden; and another disagreed, affirming the program's legality under the 2001 PATRIOT Act. ${ }^{45}$ Reasonable disagreement about the program's legality does not weaken Snowden's case for blowing the whistle if what matters is that the public ought to have known about the program's existence, as Snowden stressed in his speeches. Snowden's whistleblowing led to a national debate about civil liberties, surveillance, and privacy in the digital age, forcing the American people to think about the existence, nature, and extent of rights that may be violated through mass surveillance. Such debate is evidence of

\footnotetext{
${ }^{45}$ See Klayman v. Obama 957 F. Supp. 2d 1 (2013), and American Civil Liberties Union et al. v. James R. Clapper et al. 13 Civ. 3994 (2014).
} 
Snowden's contribution to democratic deliberation. Hence it may be argued that Manning's and Snowden's whistleblowing satisfied the subject condition, and that, in each case, the public's right to know overrode the duty to respect the allocation of power.

One may object that the subject condition begs the question of what constitutes an illegitimate state secret. The point of the government's interest in secrecy is precisely to give the government discretionary power over its use of secrecy and the exact scope of state secrets. The interest in secrecy thereby preempts individual assessment of the legitimacy and merits of the drawing of state secrets, and forecloses the possibility of making state secrets the product of collective decision-making. Moreover, through democratic elections, the government is authorized and entrusted to make decisions of that sort without public input. All this is to say that people ought to trust the government to do its job, and not decide on their own what the public ought to know.

This objection to the subject condition rightly points to the risk of misguided and dangerous government whistleblowing. As a matter of course, however, past instances of government whistleblowing have been carried out in reaction to significant-quasi-noncontroversial-informational deficits. According to a recent Frontline documentary, most NSA employees who knew about the domestic surveillance program were opposed to it and concerned with its illegality, and several NSA employees before Snowden attempted to blow the whistle internally. ${ }^{46}$ Furthermore, the risks that come with deluded government whistleblowing, on my account, are next to null if the next two conditions are properly satisfied.

As to the problem of determining the legitimate scope of secrecy when that determination is the government's exclusive domain, one should note that the same may be said about the moral duty to obey the law, which purports to exclude individual judgment of the merits of the law. ${ }^{47}$ Yet one generally recognizes that people retain, and sometimes even ought to exercise, their right to assess the merits of the law when they are faced with objectionable legal rules and orders. Similarly with the scope of state secrets, a healthy polity, and responsible government employees and contractors, should sometimes display vigilance rather than blind faith toward the government's wielding of secrecy.

\section{3.b. The act condition}

Second, the acquisition and disclosure of secret information should in general be undertaken after lawful attempts to blow the whistle have been

\footnotetext{
${ }^{46}$ See PBS Frontline, "The United States of Secrets," May 13 and 20, 2014.

${ }^{47}$ See section 2.a on the exclusionary nature of the duty to obey the law.
} 
attempted, unless there are reasons to think these would be useless. Ceteris paribus, individuals and groups concerned with what the public ignores ought to try legal, internal channels of alert before turning to unlawful means. The burden of justification of illegal whistleblowing thus weighs on the agent. Did Manning and Snowden satisfy the act condition?

In 2010, Manning, then an Army intelligence analyst in Iraq, came across a report involving Iraqi Federal Police detention, and possible torture, of 15 people for printing "anti-Iraqi" literature. Manning had the literature translated and found that it detailed corruption within the cabinet of Prime Minister Nuri Kamal al-Maliki's government. She reported the incident to her superior who told her to "drop it." She then tried to establish contact with The New York Times but without success, and ended up transmitting the documents to WikiLeaks. The fact that she tried to go up the chain of command and failed doesn't automatically justify the leaks, of course; but it may be viewed as indicating a good-faith attempt to satisfy the act condition.

By making no attempt to go up the chain and fleeing the country, in contrast, Snowden's whistleblowing seems to blatantly violate this second constraint. Yet the requirement to first attempt lawful ways to bring attention to, and halt, some wrongdoing should not be understood as a strict requirement to blow the whistle only in last resort. Indeed, the act condition is not violated if there are reasons to think that lawful attempts would be useless or counterproductive. It is worth keeping in mind that four NSA whistleblowers before Snowden had tried to pursue lawful means of alert. Thomas Drake had attempted to blow the whistle on the NSA's domestic surveillance program as soon as it was launched. Drake followed the protocol set out in the Intelligence Community Whistleblower Protection Act by complaining internally to his superiors, the NSA Inspector General, and the Defense Department Inspector General, and by presenting unclassified documents both to the House and Senate Congressional intelligence committees. Four years later, he leaked unclassified documents to The New York Times. Albeit presenting an apparently clear case of public whistleblowing, Drake was charged under the Espionage Act in 2010 (the NSA went on to classify the documents he had leaked). ${ }^{48}$ The other NSA whistleblowers have also been retaliated against and harassed by the government, though not as harshly as Drake. ${ }^{49}$ One ought to consider their experiences when evaluating Snow-

\footnotetext{
${ }^{48}$ See United States v. Drake, 130 S. Ct. 1562 (2010). The Espionage Act charges were dropped just before the trial, and Drake pleaded guilty to a misdemeanor charge under the Computer Fraud and Abuse Act (CFAA).

${ }^{49}$ For lengthy interviews with each of them, see Frontline, "The United States of Secrets."
} 
den's decisions: he had solid reasons to think he would be arrested before he could warn the public about the U.S. domestic spying. From this perspective, Snowden's leaks and search for asylum may be deemed suitably constrained.

\section{3.c. The minimize harms condition}

Government whistleblowing has disruptive and potentially harmful effects, as we saw in section 2.c. Though these potentials harms, well understood, do not justify a categorical moral prohibition, they do suggest the existence of a duty on the part of the whistleblower to minimize the harms that might result from the disclosure. To wit, the agent ought to exercise due care when releasing the information. If the information puts identifiable, innocent persons at risk (say, it exposes undercover agents), then the whistleblower must take precautions against this risk by editing names out of the documents before releasing them, and making sure the stolen documents do not fall into foreign spies' hands.

The senior Bush administration officials who exposed Valerie Plame as a CIA operative blatantly violated the minimize harms condition. Their leaks to the press, done in an attempt to discredit Plame's husband, Joe Wilson, whose fact-finding mission in Niger revealed no evidence that Saddam Hussein had bought yellowcake, put Plame's life in danger and were morally unjustifiable. One may also argue that WikiLeaks failed to exercise sufficient care by "dumping" online the 750,000 unedited documents leaked by Manning, as this may have put military personnel at risk (though they don't appear to have done so). Arguably, special care should be shown in the release of top-secret army information when military operations are ongoing. So the manner of leaking matters.

One way to minimize the harmful effects of government whistleblowing is to collaborate with professional entities such as the press to carefully edit the information before its release. Though Snowden could have published the documents about the NSA himself, he chose instead to collaborate with The Guardian's Glenn Greenwald, The Washington Post's Barton Gellman, filmmaker Laura Poitras, and the newsroom ProPublica. The editor of The Guardian, Alan Rusbridger, recently praised the "careful, responsible journalism" each source demonstrated, observing that "The Guardian, The Washington Post, ProPublica, and The New York Times have gone to exceptional lengths to edit the Snowden material with caution.. ${ }^{\text {, }}$ The recipients ensured not only that the information released

\footnotetext{
${ }^{50}$ Alan Rusbridger, "The Snowden Leaks and the Public," The New York Review of Books, 21 November 2013.
} 
would not include details that could potentially be used to injure the interests of the U.S., but also that the information would enter the public domain in the right way, by getting proper coverage and being framed adequately. In these ways, the manner of leaking and releasing the NSA documents appeared quite exemplary. It is thus reasonable to argue that Snowden's whistleblowing satisfied the minimize harms condition.

Should Manning's release of secret information be deemed suitably constrained? Witnesses for the defense at her trial included a former chief prosecutor at Guantánamo Bay and an Army security specialist, who argued that the leaks did not endanger national security. Manning was ultimately acquitted of the charge of "aiding the enemy," though found guilty on 20 other counts. The prosecution argued in closed session that the diplomatic cables identified people who had spoken to U.S. diplomats in confidence. Not only were these individuals put at risk of death, violence, or incarceration in their home country (the number of people determined to be at risk was not made public), but the prosecutors predicted that the leaks would have a "chilling effect" on human-rights activists seeking U.S. State Department help.

It is reasonable to argue, on that basis, that the diplomatic cables ought to have been sorted out and carefully edited before their release, and that Manning and WikiLeaks failed to exercise due care in that respect. Manning's decision to leak the documents to WikiLeaks, however, was well grounded, since WikiLeaks had been blowing the whistle on various human rights abuses at Guantánamo (it had released a copy of Standard Operating Procedures for Camp Delta in 2007). All in all, Manning's failure to minimize the harms that could follow the release of information may be deemed to stain the moral justification of her actions without necessarily undermining it, given the great benefits to public deliberation they brought about.

\section{4.}

I have argued that government whistleblowing may be justified when it satisfies three conditions: (A) it exposes serious government wrongdoing or programs and policies that ought to be known and deliberated about; (B) it is undertaken after lawful attempts to make the information public have been attempted, unless there are reasons to think these would be useless; and (C) the whistleblower exercises due care in the disclosure so as to minimize the harms that could potentially ensue, including carefully choosing the leaks' recipients. Constrained in these ways, government whistleblowing, or political vigilantism, still constitutes an interference with the state's allocation of power-but it can sometimes be a morally 
justified one. Government whistleblowing contributes to political deliberation, and exposes the government's lapses of legitimacy. Until such failures no longer occur, government whistleblowing will remain an imperfect but critical way of exposing illegal or morally reprehensible government practices.

The foregoing account suggests that because whistleblowers transgress the boundaries around state secrets for the purpose of alerting the collectivity to some illegitimate allocation or use of power, government whistleblowing is compatible with respect for democratic authority. John Rawls writes that one who engages in civil disobedience "addresses the sense of justice of the majority of the community and declares that in one's considered opinion the principles of social cooperation among free and equal men are not being respected." ${ }^{, 51}$ The civilly disobedient agent points out significant deviations from justice and tries to persuade the majority of the need for reform. Civil disobedience thus "serves to inhibit departures from justice and to correct them when they occur" and "helps to maintain and strengthen just institutions. ${ }^{, 52}$ It promotes justice by proposing to rectify injustices.

We should think about government whistleblowing in similar ways, as a potentially useful democratic device to inhibit government wrongdoing and enhance political legitimacy. Philosophers have long studied the democracy-enhancing function of civil disobedience, but they have neglected government whistleblowing. Journalists, on the other hand, know the significance of government whistleblowing in informing public debates. Laurie Oakes, for instance, writes that "leaks, and whistleblowers, are essential to a proper democratic system." 53 Government whistleblowers promote legitimacy by remedying serious informational deficits regarding government wrongdoing or policies objectionably shrouded in secrecy. They act as "cognitive enhancers" and "debate boosters," augmenting people's knowledge of their government's actions and invigorating public discussion.

One might welcome the parallel between civil disobedience and government whistleblowing but stress that the conditions I have laid out neglect the necessity of civility, which accounts of civil disobedience generally emphasize. Martin Luther King, Jr., for instance, distinguished between Civil Rights activists' and segregationists' legal disobedience by observing that the former, unlike the latter, disobeyed the law "openly,

\footnotetext{
${ }^{51}$ John Rawls, A Theory of Justice, revised ed. (Cambridge, Mass.: Harvard University Press, 1999 [1971]), p. 320.

${ }^{52}$ Ibid., p. 336.

${ }^{53}$ Laurie Oakes, "Pillars of Democracy Depend on Leaks," The Bulletin, 24 August 2005.
} 
lovingly, and with a willingness to accept the penalty." 54 Similarly, Rawls claimed that for disobedience to be civil, it must be nonviolent, open, and public, and the agent must recognize the legitimacy of the state and be willing to accept the punishment. ${ }^{55}$

By publicizing in advance one's intention to protest, submitting to arrest, and willingly accepting the penalty for violating the law, as publicity and openness require, civil disobedients demonstrate their sincere commitment to the cause and operate "within the limits of fidelity to law." ${ }^{, 56}$ These features mark the act's civility, which is crucial to its communicative function (i.e., its transparency as an address to the community) and its conception as a form of political participation. ${ }^{57}$ Since the instances of government whistleblowing I have discussed lack such marks of civility-Snowden did not warn the authorities of his intention to leak classified documents, for instance; and he blew the whistle from outside the U.S. so as to escape punishment - they cannot be justified, let alone be compatible with democratic authority.

A number of theorists have refuted the Rawlsian view that these marks of civility-nonviolence, openness, publicity, recognition of state legitimacy, and willingness to accept punishment - are necessary for the definition or justification of civil disobedience. ${ }^{58}$ For instance, Brian Smart notes that advance warning to the authorities can sometimes guarantee an arrest and preclude the undertaking of the civilly disobedient act. ${ }^{59}$ David Lyons observes that the requirement that the agent recognize the state's overall legitimacy is historically implausible in the case of Henry David Thoreau, Mohandas Gandhi, and Martin Luther King, Jr. (whom theorists view as paragons of civil disobedience), and morally untenable in the face of chattel slavery, British colonial rule in India, and Jim Crow. ${ }^{60}$ Brownlee objects to the requirement that the agent be willing to accept

${ }^{54}$ Martin Luther King, Jr., "Letter from a Birmingham Jail," in Hugo Adam Bedau (ed.), Civil Disobedience in Focus (New York: Routledge, 1991), chap. 4, p. 74.

${ }^{55}$ Rawls, A Theory of Justice, p. 320. Rawls even makes it a defining feature of civil disobedience. I shall merely treat it as a necessary condition for the justification of civil disobedience here.

${ }^{56}$ Ibid.

${ }^{57}$ See, e.g., William Smith, Civil Disobedience and Deliberative Democracy (New York: Routledge, 2013).

${ }^{58}$ For an overview of these critiques, see Kimberley Brownlee, "Civil Disobedience," in Edward N. Zalta (ed.), The Stanford Encyclopedia of Philosophy (Fall 2008 Edition); http://plato.stanford.edu/archives/fall2008/entries/civil-disobedience/.

${ }^{59} \mathrm{In}$ his view, all that is needed is a declaration of intention made after the fact. See Brian Smart, "Defining Civil Disobedience," in Bedau (ed.), Civil Disobedience in Focus, chap. 12, p. 206.

${ }^{60}$ David Lyons, "Moral Judgment, Historical Reality, and Civil Disobedience," Philosophy \& Public Affairs 27 (1998): 31-49. 
punishment that if an act of civil disobedience is a morally justified exercise of the right to engage in civil disobedience, then it ought not to be punished. ${ }^{61}$ She further rebuts the standard assumption that all violence necessarily obscures the communicative quality of the disobedient act. ${ }^{62}$ In short, though the features of civility may well be desirable, they should not be deemed necessary to justify civil disobedience.

Neither are they necessary to justify government whistleblowing. It does not matter whether the agent accepts or denies the state's overall legitimacy so long as her disclosure remedies a significant informational deficit (which, at a minimum, constitutes a stain on political legitimacy) and is suitably constrained. The agent's willingness to accept punishment has symbolic significance, as it demonstrates her sincere commitment to the cause, and can play an important strategic role, by ensuring, or increasing the chances, that people see the illegal act as a public address to the community. But government whistleblowing, unlike certain other forms of illegal protest, already presents itself as a public address, since to blow the whistle is to alert the authorities or the public. Moreover, other things can demonstrate the agent's sincere commitment besides her willingness to accept punishment, such as Snowden's self-sacrifice as he condemned himself to a life in exile or in prison. Whistleblowers in general have more to lose than to gain from their whistleblowing-even when they are legally protected. ${ }^{63}$

Though the cases of government whistleblowing I considered were not anonymous, I would like to end by briefly examining whether anonymous whistleblowing might be morally justified. There are many instances of anonymous government whistleblowing in the history of the U.S. The members of the Citizens Commission to Investigate the FBI, who broke into an FBI office and stole files that revealed the FBI's elaborate program of spying on dissident groups (known as COINTELPRO), concealed their identity for 40 years. "Deep Throat," the FBI agent who leaked information to the Washington Post about the Watergate scandal, remained anonymous for over 30 years. Anonymity violates the openness and publicity requirements, on most accounts of civil disobedience. Anonymity

\footnotetext{
${ }^{61}$ Kimberley Brownlee, “Penalizing Public Disobedience,” Ethics 118 (2008): 711-16.

${ }^{62}$ Kimberley Brownlee, "Features of a Paradigm Case of Civil Disobedience," Res Publica 10 (2004): 337-51, pp. 349-50.

${ }^{63}$ On the costs of whistleblowing, see, e.g.: Myron P. Glazer and Penina M. Glazer, The Whistleblowers: Exposing Corruption in Government and Industry (New York: Basic Books, 1989), p. 7; Joyce Rothschild and Terance D. Miethe, "Whistle-Blower Disclosures and Management Retaliation," Work and Occupations 6 (1999): 107-28; Alan F. Westin, Whistle Blowing! Loyalty and Dissent in the Corporation (New York: McGraw-Hill, 1981); and C. Fred Alford, Whistleblowers, Broken Lives and Organizational Power (Ithaca: Cornell University Press, 2001).
} 
is seen as counterproductive and self-defeating when it comes to addressing the community, because it arouses suspicions as to the true motives of the agent and obfuscates the message.

Does the same apply to government whistleblowing? The answer is "no." Anonymous government whistleblowing is morally justifiable, in my view, because of the enormous prudential costs whistleblowers face (including the probability of retaliation, loss of career, risk of lengthy punishment, and externalities such as impact on the family). ${ }^{64}$ The journalists with whom Snowden collaborated advised him to remain an anonymous source; his blowing the whistle anonymously would have been morally justified in the circumstances, especially judging from what happened to the previous NSA whistleblowers.

Let me conclude with some implications of the foregoing account on the proper treatment of government whistleblowers by democratic societies. First, internal channels of grievances should be made much more responsive and efficient so as to diminish whistleblowers' resort to illegal leaks. Second, legislation should be enacted to protect workers and contractors in areas where protections are currently weak or lacking (such as intelligence work). Third, governments' prosecution of whistleblowers as traitors and spies is disproportionate and unjust. Neither the Espionage Act, nor the Organized Crime Control Act (aka RICO, which has recently been updated to prosecute hackers), nor the Computer Fraud and Abuse Act (on the basis of which Manning and Drake were sentenced) constitute appropriate frameworks to deal with government whistleblowers, who are not ordinary criminals, but morally motivated, civic-minded law-breakers. Fourth, something like a "public's right to know" defense should be available in court for government whistleblowers who broke the law, so as to give them a chance to justify their actions; and guidelines for leniency in sentencing should be provided. The protections currently afforded conscientious objectors could further provide the legal basis for extending some of the same protections to whistleblowers. ${ }^{65}$

\section{Department of Philosophy and Religion, Clemson University} candice.delmas@gmail.com

\footnotetext{
${ }^{64}$ Other theorists have defended the moral permissibility of anonymous whistleblowing. See, e.g.: James Rocha and Edward Song, "Pre-Emptive Anonymous Whistleblowing," Public Affairs Quarterly 26 (2012): 257-71; and Frederick Elliston, "Anonymity and Whistleblowing," Journal of Business Ethics 1 (1982): 167-77.

${ }^{65}$ I am grateful to Sean Aas, Chris Grau, faculty and students at Wellesley College and Georgia State University, and two anonymous reviewers for Social Theory and Practice for their helpful comments on previous drafts of this paper.
} 